\title{
Influence of debris cover on terminus retreat and mass changes of Chorabari Glacier, Garhwal region, central Himalaya, India
}

\author{
D.P. DOBHAL, Manish MEHTA, Deepak SRIVASTAVA \\ Centre for Glaciology, Wadia Institute of Himalayan Geology, Dehra Dun, Uttarakhand, India \\ E-mail:msmehta75@gmail.com
}

\begin{abstract}
Recent studies of Himalayan glacier recession indicate that there is wide variability in terminus retreat rate and mass balance in the different sectors of the mountain range, primarily linked to the topography and climate of the region. Variable retreat rates of glacier termini and inadequate supporting field data (e.g. mass balance, ice thickness, velocity, etc.) in the Himalayan glaciers make it difficult to develop a coherent picture of climate change impacts. In this study, the results of a detailed mapping campaign and ground-based measurements of ablation rate, terminus retreat and ice loss are reported for the period 2003-10. In addition, background information from an old glacier map (Survey of India, 1962) was compiled and terminus recession measurements were carried out from 1990 field photographs of Chorabari Glacier, central Himalaya. Our ablation stake network results suggest that the influence of debris cover is significant for Chorabari Glacier mass balance and terminus retreat. The terminus survey finds that the glacier is retreating, but at a lower rate than many other non-debriscovered glaciers in the region. The recession and ablation data (particularly in the upper ablation area at higher altitudes) suggest that the ice volume loss of the glaciers is of greater magnitude than the slow terminus retreat and, if the process continues, the lowermost part of the glacier may reduce to a quasistationary position while significant ice loss continues.
\end{abstract}

\section{INTRODUCTION}

The Himalayan mountain range contains thousands of glaciers of widely varying properties, which are spread over nearly $37000 \mathrm{~km}^{2}$ with an east-west range $>2000 \mathrm{~km}$ (Raina and Srivastava, 2008). This large geographic extent, with complex and extreme topography along with variable climatic conditions, results in an inhomogeneous set of glacial recessions. The primary climatic forcing, moving from west to east, is a decreasing influence of the midlatitude westerlies and an increasing influence of the Indian summer monsoon (Bookhagen and Burbank, 2010). Thus, the distribution of glaciers in the Himalaya is uneven, with a higher concentration of glaciers in the northwest than in the northeast of the mountain range. In general, glaciers in the region have debris-covered ablation areas with debris thickness ranging from millimetres to tens of centimetres. As a consequence of the complex climate system, glacial geometry, glacier surface properties and geology, the recession rates of the glaciers are variable (Scherler and others, 2011).

Various studies, such as mapping of debris-cover extent and its correlation with glacier melting and recession, have been carried out using remote-sensing and field-based data in different parts of the world (Lougeay, 1974; Bishop and others, 2001; Taschner and Ranzi, 2002; Paul and others, 2004; Buchroithner and Bolch, 2007; Stokes and others, 2007; Bolch and others, 2008; Shukla and others, 2009; Kamp and others, 2011; Scherler and others, 2011). Supraglacial debris on glaciers is commonly found to have significant control on the rate of ice ablation (Bozhinsky and others, 1986; Lundstrom and others, 1993). A debris cover influences the terminus dynamics and modifies a glacier's response to climate change (Scherler and others, 2011). Surface ablation rates are generally increased in the presence of a thin $(<5 \mathrm{~cm})$ debris cover, but are significantly reduced when a thick $(>5 \mathrm{~cm})$ debris cover is present (Østrem, 1965; Lundstrom and others, 1993; Mattson and others, 1993; Reznichenko and others, 2010; Scherler and others, 2011). A thin and patchy debris cover reduces the albedo and elevates shortwave radiation absorption, whereas ablation rates are strongly reduced further down the glacier due to the insulating effect of thicker debris (Mattson and others, 1993; Jackson and Fountain, 2007; Reznichenko and others, 2010). The local mass balance of debris-covered glaciers is distinctly nonlinear and nonmonotonic with elevation. Generally ablation takes place below the equilibrium-line altitude (ELA) and ablation rates increase with decreasing elevation; however, at Chorabari Glacier at lower altitudes, where the debris cover thickens to $>5 \mathrm{~cm}$, ablation rate decreases.

In the central Himalaya a large number of glaciers are debris-covered, especially in the ablation zone, which can exist over stagnant termini. Over some glacier surfaces, growing meltwater ponds and surface lowering due to internal melting indicate that these glaciers are downwasting on the whole. This paper presents recent results of ablation observations on Chorabari Glacier from 2003 to 2010. Our aim is to quantitatively evaluate the influence of the debris cover on summer ablation and terminus recession and to discuss the effects of debris cover on mass-balance processes.

\section{Study site}

Chorabari Glacier $\left(30^{\circ} 46^{\prime} 20.58^{\prime \prime} \mathrm{N}\right.$; $\left.79^{\circ} 2^{\prime} 59.381^{\prime \prime} \mathrm{E}\right)$ is a medium-sized compound valley-type glacier covering an area of $\sim 6.6 \mathrm{~km}^{2}$. The glacier is located in the Mandakini River basin of the Alaknanda catchment (a tributary of the River Ganga) (Fig. 1a). Chorabari Glacier has its accumulation area below Bhartkhunta peak (6578 ma.s.l.) and Kedarnath peak (6940ma.s.l.) and flows from north to south between 6400 and 3895 ma.s.l. with an average 

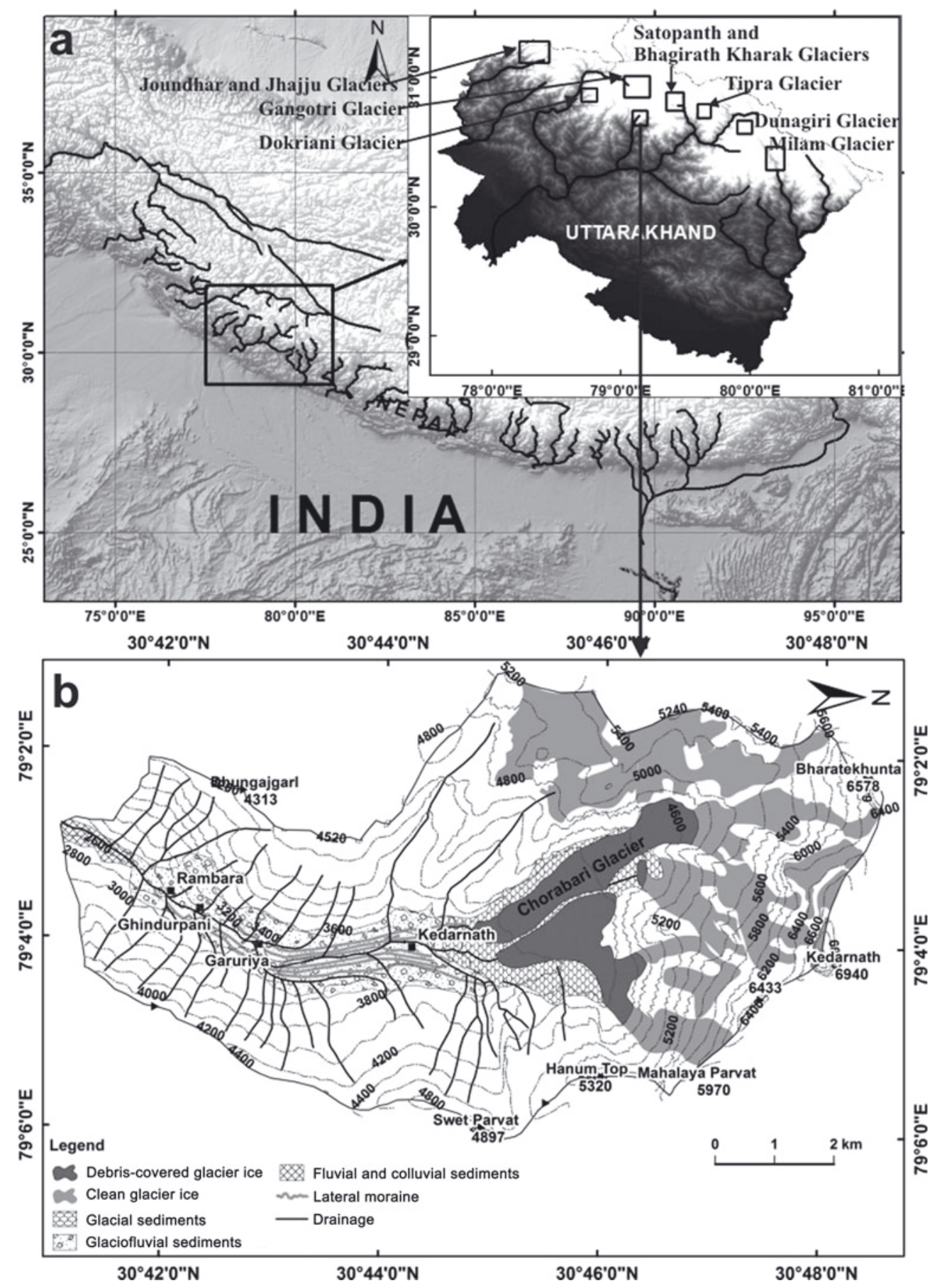

Fig. 1. (a) Location of Chorabari Glacier and adjacent glaciers in the Garhwal Himalaya showing the major river systems of the Indian Himalaya. (b) Geomorphic overview of Chorabari Glacier and the extension of lateral moraine up to Rambara ( 2800 m a.s.l.).

surface slope of $20^{\circ}$ (Fig. 1b). The key feature of this glacier is its small accumulation area formed by three steep-sloped tributary glaciers, whereas the ablation area is broad with a gentle slope and covered by thick debris. The debris-covered area accounts for $\sim 53 \%$ of total glacier area. A number of longitudinal and transverse crevasses and several small supraglacial ponds are present in the ablation zone. Debris thickness increases along the glacier and is $>50 \mathrm{~cm}$ at the terminus (Fig. 2). A second unnamed glacier (4.5 km long) flows parallel to Chorabari; it ranges from 3810 to $4250 \mathrm{~m}$ a.s.l. and its area is $\sim 3.5 \mathrm{~km}^{2}$. The ablation area has a thick debris layer covering $\sim 80 \%$ of the total area of the glacier. It does not have a well-defined accumulation zone and accumulation is received mostly from avalanches.
The glacier can be considered quasi-stationary as no terminus retreat was observed during the study period. A huge modified medial moraine (Fig. 2) suggests that the two glaciers may once have been one, now separated by recession. The extension of lateral moraines is observed up to $6 \mathrm{~km}$ downstream at Rambara town (2800 m a.s.l.), which is $\sim 13 \pm 2 \mathrm{ka}$ old (Mehta and others, 2012). There appear to have been five stages of recession, the records of which are well preserved by traces of the lateral moraine throughout the valley (Fig. 1b; Mehta and others, 2012). In summary, the characteristic features of this glacier are that it is southfacing and has a wide and broad terminus that is thickly debris-covered. Some of the salient properties of the glacier are given in Table 1. 


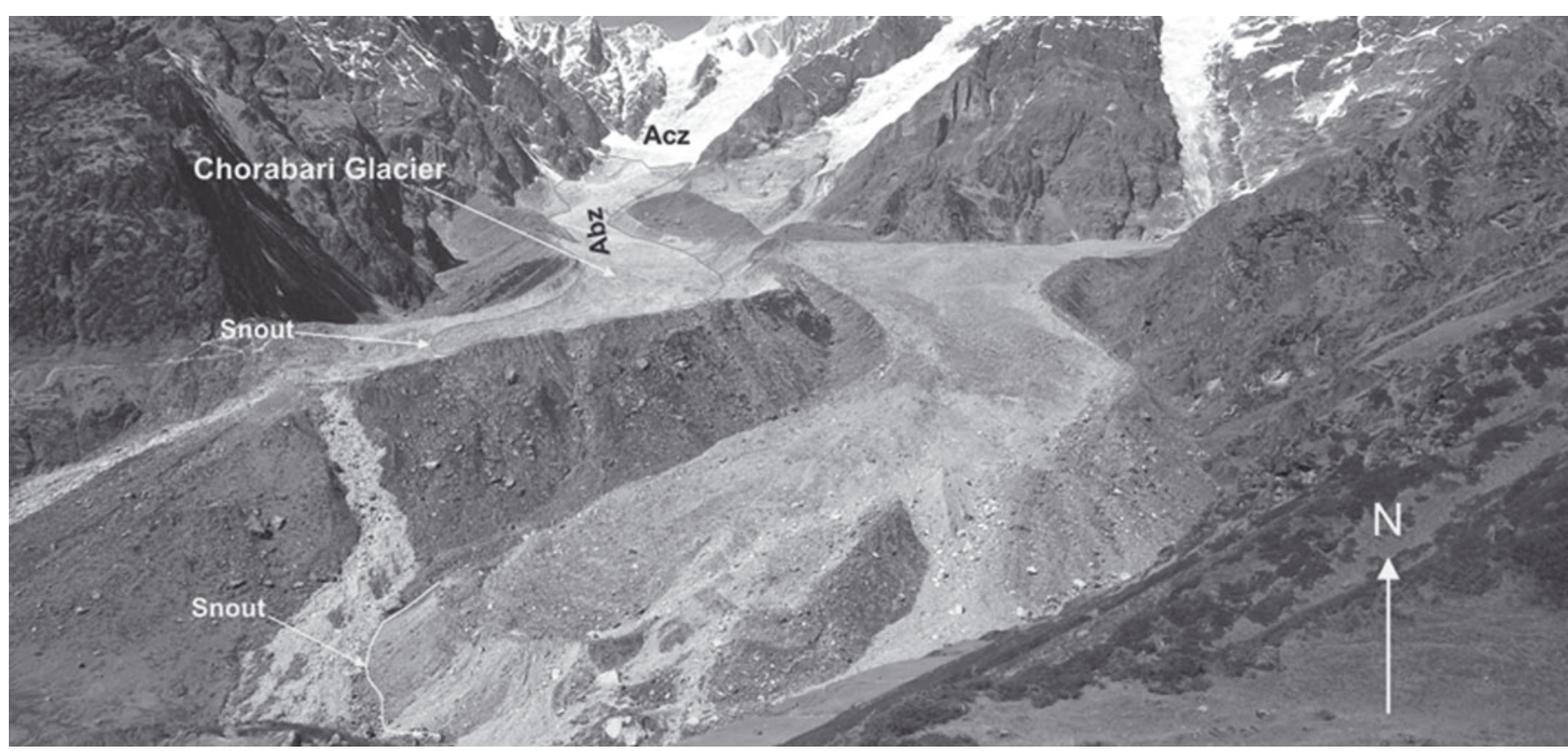

Fig. 2. Chorabari Glacier showing the clean accumulation zone (Acz) and debris-covered ablation zone (Abz). On the right-hand side is an unnamed glacier with thick debris cover $\left(3.5 \mathrm{~km}^{2}\right)$ flowing parallel to Chorabari.

\section{General climatic setting}

The area is precipitated by the Indian summer monsoon in summer and westerly disturbances in winter (Owen and others, 1996). Vohra (1981) suggested that the Ganga basin experiences equal amounts of summer monsoon precipitation and winter westerly precipitation. Therefore these glaciers are also called summer as well as winter accumulation type glaciers (Vohra, 1981; Ageta and Higuchi, 1984; Higuchi and Ohata, 1996).

The general climate of the study area is humid-temperate in summer and dry-cold in winter. There are no long-term instrumental data available for weather parameters. The

Table 1. Salient features and geomorphological parameters of Chorabari Glacier

\section{Coordinates}

Surface area (1962)

Surface area (2010)

Ablation area (2010)

Accumulation area (2010)

Length (2010)

Orientation

Elevation extension

Average surface slope

Ablation slope

Accumulation slope

Mean total width

ELA (2010)

AAR (2010)

General climate

Temperature at $3820 \mathrm{~m}$ a.s.l. (2007-10)

Geology (rock type) $30^{\circ} 46^{\prime} 20.58^{\prime \prime} \mathrm{N}, 79^{\circ} 2^{\prime} 59.381^{\prime \prime} \mathrm{E}$

$$
\begin{aligned}
& \sim 7.37 \mathrm{~km}^{2} \\
& \sim 6.66 \mathrm{~km}^{2} \\
& \sim 3.67 \mathrm{~km}^{2} \\
& \sim 2.99 \mathrm{~km}^{2} \\
& \sim 7.5 \mathrm{~km} \\
& \quad \text { South }
\end{aligned}
$$

3895-6420 m a.s.I.

$$
\begin{gathered}
20^{\circ} \\
10^{\circ} \\
30^{\circ} \\
0.43 \mathrm{~km} \\
5070 \mathrm{~m} \\
0.44
\end{gathered}
$$

Humid temperate in summer and dry cold in winter

Annual daily average $3.4^{\circ} \mathrm{C}$

Daily maximum $16.04^{\circ} \mathrm{C}$ (Jun 2007)

Daily minimum $-18^{\circ} \mathrm{C}$ (Jan 2008) Crystalline rocks, mainly augen and granitic gneisses monitoring of Chorabari Glacier began in 2003 and a manned meteorological observatory (3820 ma.s.I.) was installed to monitor air temperature, wind speed and precipitation during the investigation period. In 2007, an automatic weather station (AWS; Campbell Scientific) was installed near the terminus of the glacier at 3820 ma.s.l. Daily mean temperature was found to fluctuate between $+12^{\circ} \mathrm{C}$ and $-1^{\circ} \mathrm{C}$ (June-October) during the period 2003-10. Maximum air temperature was $16.6^{\circ} \mathrm{C}$ in June 2009 , and the minimum was $-18^{\circ} \mathrm{C}$ in January 2008. Summer precipitation is highly influenced by the monsoon and average rainfall recorded between 2007 and 2010 was 1253 mm (JuneOctober). Winter precipitation generally occurs between December and March (when the westerlies are dominant in the area as they move eastward over northern India) and is the main source of snow accumulation. There are no instrumental data available for winter snowfall; however, residual snow depth fluctuated between 25 and $50 \mathrm{~cm}$ in April and early May at $4000 \mathrm{~m}$ a.s.l. during the study period from 2003 to 2010. Snow normally melts before the monsoon commences in mid-June. The average wind speed at the AWS was $2.5 \mathrm{~m} \mathrm{~s}^{-1}$ and average daily sunshine duration was 190 min between 2007 and 2010 (Fig. 3a). The measured daily mean temperature and rainfall are shown in Figure 3b.

\section{STUDY METHODS \\ Glacier survey}

The earliest record of Chorabari Glacier is available in the Survey of India (1962) topographic map on 1:50000 scale with $40 \mathrm{~m}$ contour interval (planimetric accuracy $\pm 12.5 \mathrm{~m}$ and elevation accuracy $\pm 6.5 \mathrm{~m}$; Prasada Raju and Ghosh, 2003). In 1990, the terminus (snout) position was marked and the glacier was photographed. Changes in the terminus position were measured (fixed date) during the field seasons of 2003-10 with handheld GPS (Magellan, Pro Mark-X) with vertical accuracy $(z) 1-5 \mathrm{~m}$ and horizontal accuracy $(x, y)$ 

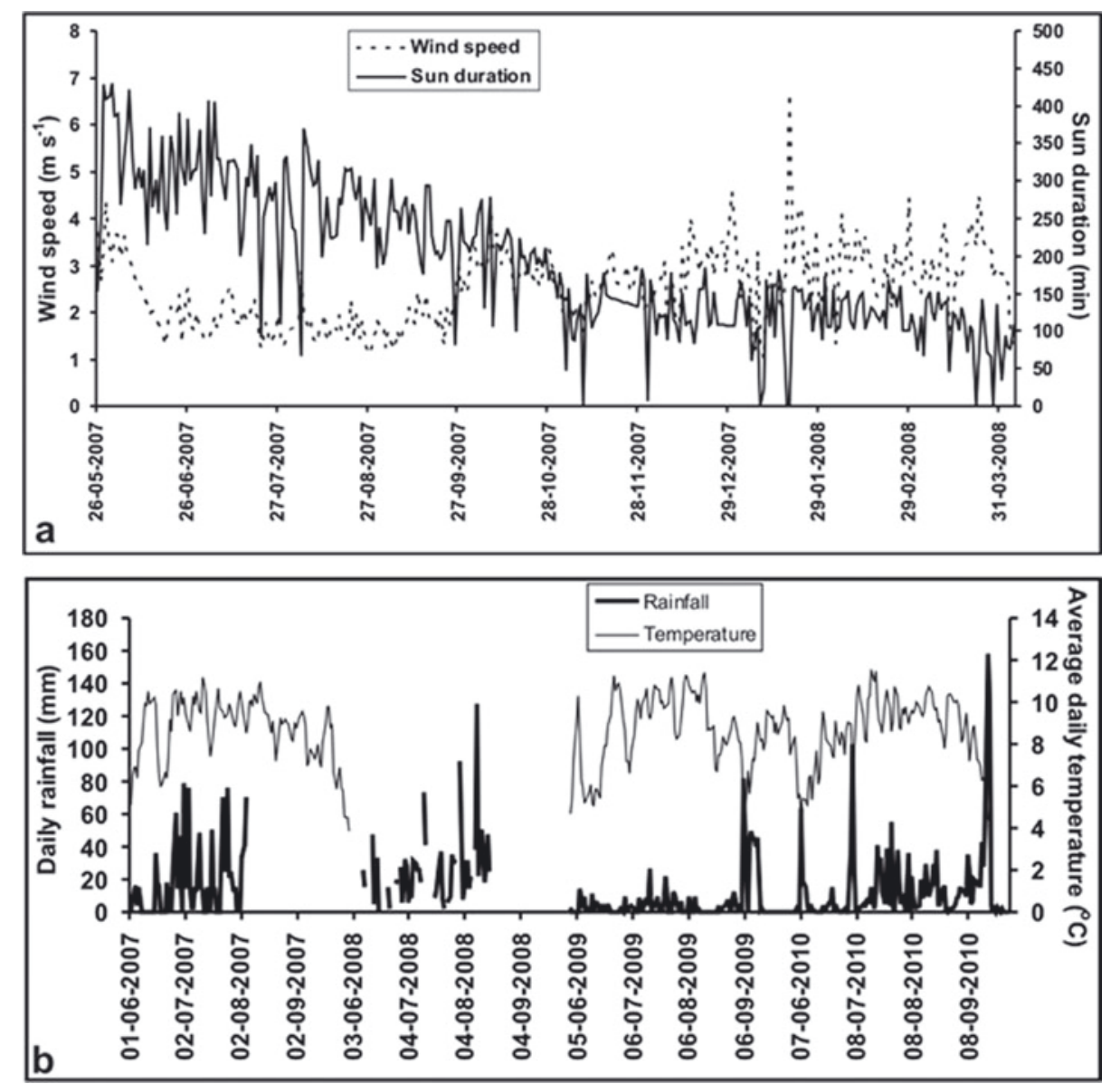

Fig. 3. Meteorological data collected during the study period from an AWS at $3820 \mathrm{~m}$ a.s.l.: (a) wind speed and sun duration; (b) average daily temperature and rainfall. Date format is day-month-year.

$3 \mathrm{~m}\left(0.01^{\prime}\right)$ and survey-grade total station measurements from the fixed stable survey point (see Fig. 5a further below). The area vacated by the glacier due to recession was estimated by comparing the field measurements with the Survey of India (1962) map. The annual monitoring of glacier terminus position, frontal area loss, surface volume loss and elevation change was undertaken following wellestablished techniques (Østrem and Brugman, 1991; Dobhal and others, 2004, 2008; Wagnon and others, 2007).

\section{Mass-balance and debris thickness measurement}

Mass-balance measurements were undertaken by the glaciological stake network method (Østrem and Brugman, 1991). In October 2003 a network of 44 stakes was set up and each stake was fixed to a depth of $10-12 \mathrm{~m}$ by stream drill (Heucke ice drill) to measure the accumulation, ablation and debris thickness (Fig. 4a). However, in the upper ablation zone (4400-4600 ma.s.I.) a few stakes were lost in winter. These were replaced as per standard procedure. The process was repeated in each measurement year as the area is steeply sloped, with a bare ice surface in the upper ablation region and thick debris cover in the lower ablation region. These stakes were labelled Nos. 01-44 in sequence from the terminus to the accumulation area. Stake height readings were taken at an interval of 5-10 days during the entire ablation period to determine monthly melting and net ablation. Accumulation measurements were made in snow pits and by probing at different locations. These measurements were made in April-May (early summer) and again in
October each year. Snowpack density was measured at various altitudes. The density measured in several pits at different altitudes was used to assess water equivalent measurement. Average densities of 0.56 and $0.85 \mathrm{~g} \mathrm{~cm}^{-3}$ were calculated for snow-firn and ice, respectively. Stake locations, obtained by total station and handheld GPS, were transferred to the map for further analysis. In addition, based on the Survey of India (1962) topographic map, Landsat Enhanced Thematic Mapper Plus (ETM+) imagery (2005) glacier outlines were delineated and a contour map prepared. The outlines of debris cover were manually delineated. The surface area of each elevation band was calculated using a planimeter and multiplied by the calculated value of net accumulation/ablation for each elevation band used for final calculation of net mass balance for a budget year. The standard error, estimated to be $10 \%$ of total mass balance, comprises stake height measurement, snow ice density variation and extrapolation for inaccessible crevasse-prone areas (Wagnon and others, 2007; Dobhal and others, 2008).

The distribution of ablation stakes for measurement of melting and debris thickness was divided into three categories: clean ice (stake Nos. 35-40), thin debris cover $\leq 5 \mathrm{~cm}$ (stake Nos. 25-34) and thick debris cover $>5 \mathrm{~cm}$ (stake Nos. 01-24). Maximum debris thickness measured was $\sim 1.8 \mathrm{~m}$ in the lower ablation zone near the glacier terminus (Fig. 4c). In order to study the influence of debris thickness on the ablation process, the area was divided into four different altitude zones (Fig. 4b): (1) below 4300 m a.s.I., (2) between 

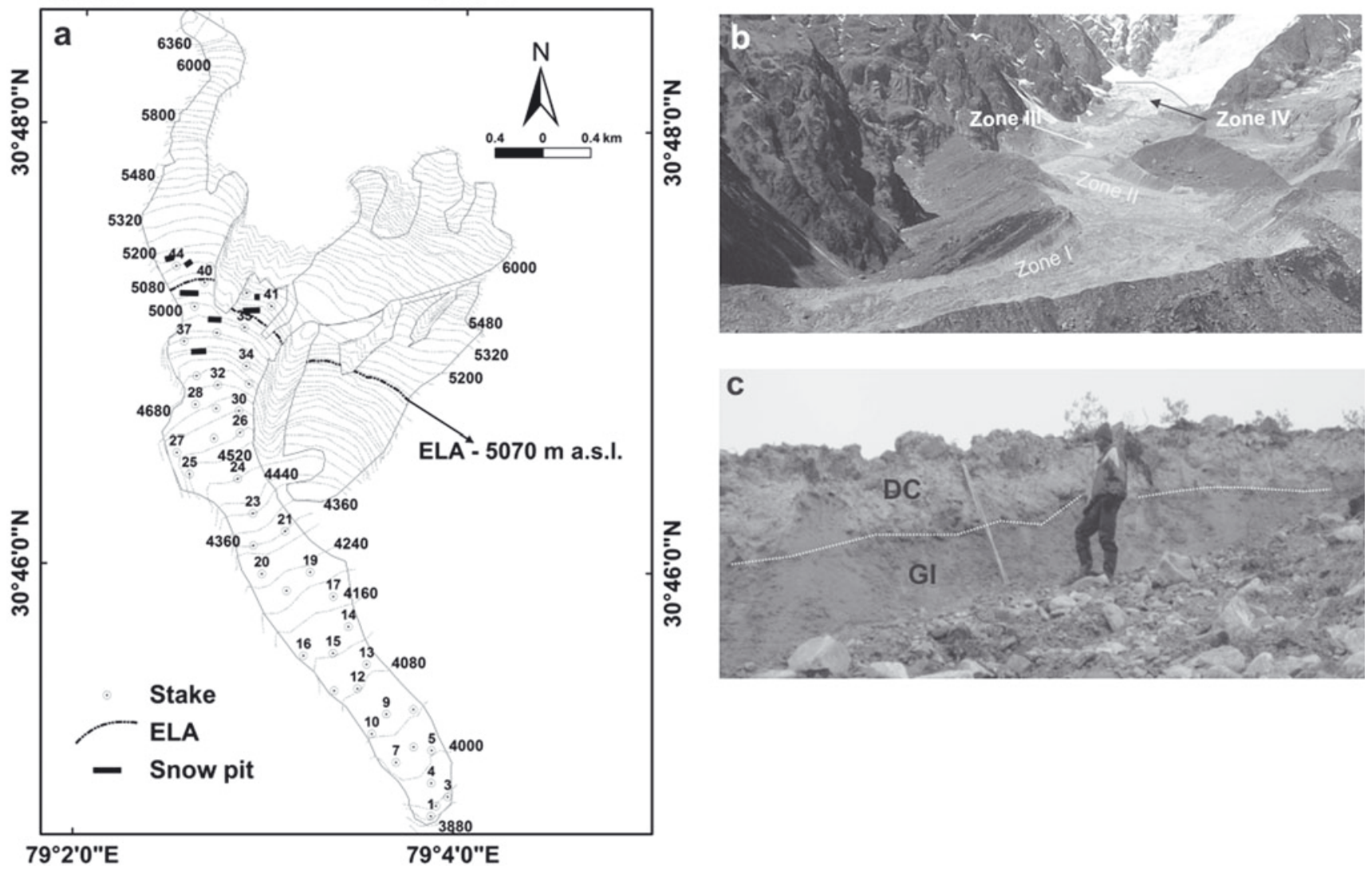

Fig. 4. (a) Contour map and stake network for accumulation/ablation measurement; circles denote stake and snow-pit locations. (b) Photograph showing ablation stake zones. (c) Debris thickness of $\sim 1.3 \mathrm{~m}$ near the left margin of the glacier termini (DC: debris cover; GI: glacier ice). Photograph taken on 30 June 2010.

4300 and 4500 ma.s.l., (3) between 4500 and 4800 ma.s.l. and (4) between 4800 and $5100 \mathrm{~m}$ a.s.l. These stakes were measured every 5-10 days throughout the summer period (May-October 2003-10) to estimate the net ablation at different altitudes. In addition, the locations of ablation stakes were used to plot the debris thickness on the map.

\section{RESULTS}

\section{Terminus retreat and area loss}

In order to examine the terminus retreat and area loss of Chorabari Glacier during the period 1962-2010, three sets of data were obtained: (1) total terminus retreat from 1962 to 2003 was $\sim 262 \mathrm{~m}$ at an average rate of $6.4 \mathrm{~m} \mathrm{a}^{-1}$; (2) field observations from 2003 to 2010 indicate that the glacier receded $\sim 65 \mathrm{~m}$ at an average rate of $9.3 \mathrm{~m} \mathrm{a}^{-1}$ (Table 2); and (3) total cumulative retreat from 1962 to 2010 was $327 \mathrm{~m}$ at an average rate of $6.8 \mathrm{~m} \mathrm{a}^{-1}$. Thus investigation indicates that the terminus of the glacier is continuously retreating at varying rates (Fig. 5a and b). We find that the long-term average retreat rate has increased significantly from 6.4 (1962-2003) to $9.3 \mathrm{~m} \mathrm{a}^{-1}$ (2003-10).

Overall, the results reveal that the average recession rate for Chorabari Glacier is lower than that of other glaciers studied in the region, with rates between 15 and $25 \mathrm{~m} \mathrm{a}^{-1}$ and one exceptional case, Joundhar Glacier, with a retreat rate of $40 \mathrm{~m} \mathrm{a}^{-1}$ (Fig. 6; Dobhal and others, 2004; Kulkarni and others, 2005, 2007; Raina, 2009; Mehta and others,
2011, 2013). The data show that these Himalayan glaciers are experiencing continuous enhanced retreat rates (Fig. 6).

The area loss from Chorabari Glacier in its proglacial region during the study period has been computed by comparing toposheet maps (Survey of India, 1962) with field measurements. The total area lost by the glacier for the period 1962-2010 was $\sim 0.712 \mathrm{~km}^{2}$, an average rate of $0.015 \mathrm{~km}^{2} \mathrm{a}^{-1}$. Approximately $12 \%$ of the total loss took place in the past 7 years $\left(0.062 \mathrm{~km}^{2}\right)$ (Table 3$)$.

Table 2. Snout recession of Chorabari Glacier during the period $1962-2010$. The error $(\sigma)$ is calculated from the total retreat from the left, right and central part of the snout

\begin{tabular}{lrrr}
\hline Period & Number of years & $\begin{array}{c}\text { Recession } \\
\text { m }\end{array}$ & $\begin{array}{c}\text { Average recession } \\
\mathrm{m} \mathrm{a}^{-1}\end{array}$ \\
\hline $1962-90$ & 28 & $180 \pm 8.48$ & 6.43 \\
$1990-2003$ & 13 & $82 \pm 5.66$ & 6.31 \\
$2003 / 04$ & 1 & $8 \pm 0.86$ & 8.00 \\
$2004 / 05$ & 1 & $10 \pm 0.77$ & 10.00 \\
$2005 / 06$ & 1 & $12 \pm 0.88$ & 12.00 \\
$2006 / 07$ & 1 & $10 \pm 0.70$ & 10.30 \\
$2007 / 08$ & 1 & $12 \pm 0.50$ & 12.50 \\
$2008 / 09$ & 1 & $5 \pm 0.50$ & 5.00 \\
$2009 / 10$ & 1 & $8 \pm 0.60$ & 8.00 \\
Total & 48 & 327 & 6.80 \\
\hline
\end{tabular}



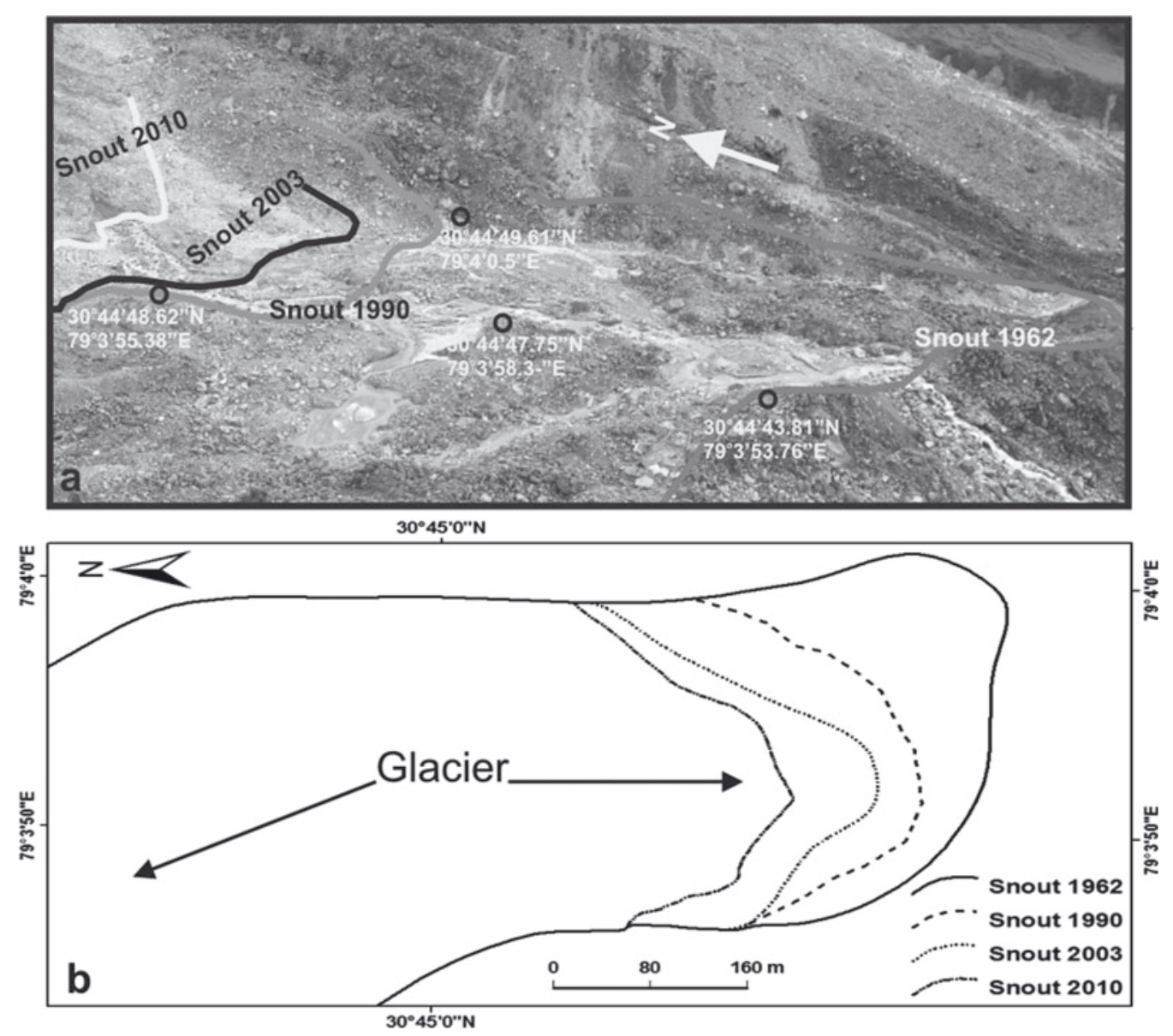

Fig. 5. Frontal retreat of Chorabari Glacier. (a) Photograph showing the different snout positions and benchmarks for termini survey (black circle). (b) Map of terminus positions and retreat of glacier during the period between 1962 (Survey of India, 1962) and 2003-10 (field survey).

\section{Annual mass balance, surface elevation and mass loss}

Annual mass balance of the glacier is calculated by integrating values (accumulation and ablation) obtained from field measurements between 2003/04 and 2009/10 (Fig. 7). The result is that the net balance over these 7 years showed a negative trend ranging from $-4.97 \times 10^{6} \mathrm{~m}^{3}$ w.e. in $2005 / 06$ to $-3.9 \times 10^{6} \mathrm{~m}^{3}$ w.e. in 2007/08 (Table 4). Based on the stake data (accumulation/ablation), we calculate total mass loss to be $30.8 \times 10^{6} \mathrm{~m}^{3}$ w.e. at an average of $4.4 \times 10^{6} \mathrm{~m}^{3}$ w.e. $\mathrm{a}^{-1}$ over the 7 year period. We estimate the average specific balance to be $-0.73 \mathrm{~m}$ w.e. $\mathrm{a}^{-1}$. During the measurement period, specific mass balance of the glacier is strongly negative, reaching $-0.82 \mathrm{mw}$.e. in 2005/06. Subsequently its magnitude decreased to reach

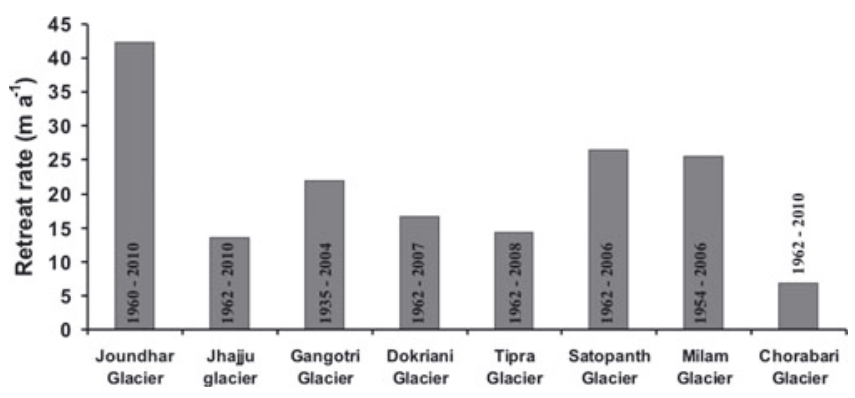

Fig. 6. Histogram showing terminus retreat rates of glaciers near Chorabari Glacier (Fig. 1a).
-0.65 m w.e. in 2009-10 (Table 4). The study also reveals that mass wasting in the ablation zone ranged from -0.46 to -2.97 m w.e. $\mathrm{a}^{-1}$, while the mass gain in the accumulation area ranged from +0.42 to $+0.94 \mathrm{~m}$ w.e. $\mathrm{a}^{-1}$ between 2003/ 04 and 2009/10. The ELA ascended $\sim 15 \mathrm{~m}$ between 2003/ 04 and 2009/10 (Fig. 7) and the average accumulation-area ratio (AAR) was calculated to be $\sim 0.44$ for the period 2003-10 (Table 4).

Surface elevation changes between 2003 and 2010 were measured by monitoring ablation stakes installed along the centre line as well as along a line transverse to flow (Fig. 4a). The surface elevation loss is spatially variable, with a maximum value of $20 \mathrm{~m}$ in the ablation zone between 4500 and 4300 ma.s.l. and a minimum of $3 \mathrm{~m}$ near the

Table 3. Total and frontal area vacated by Chorabari Glacier (19622010). Glacier area loss is $\sim 11 \%$ between 1962 and 2010 (48 years)

\begin{tabular}{lrcccc}
\hline Period & Years & $\begin{array}{c}\text { Total area } \\
\text { vacated } \\
\mathrm{km}^{2}\end{array}$ & $\begin{array}{c}\text { Annual } \\
\text { average } \\
\mathrm{km}^{2} \mathrm{a}^{-1}\end{array}$ & $\begin{array}{c}\text { Frontal area } \\
\text { vacated } \\
\mathrm{km}^{2}\end{array}$ & $\begin{array}{c}\text { Annual } \\
\text { average } \\
\mathrm{km}^{2} \mathrm{a}^{-1}\end{array}$ \\
\hline $1962-2003$ & 41 & 0.650 & 0.016 & 0.058 & 0.0014 \\
$2003-2010$ & 7 & 0.062 & 0.009 & 0.014 & 0.0020 \\
Total & 48 & 0.712 & 0.015 & 0.072 & 0.0015
\end{tabular}




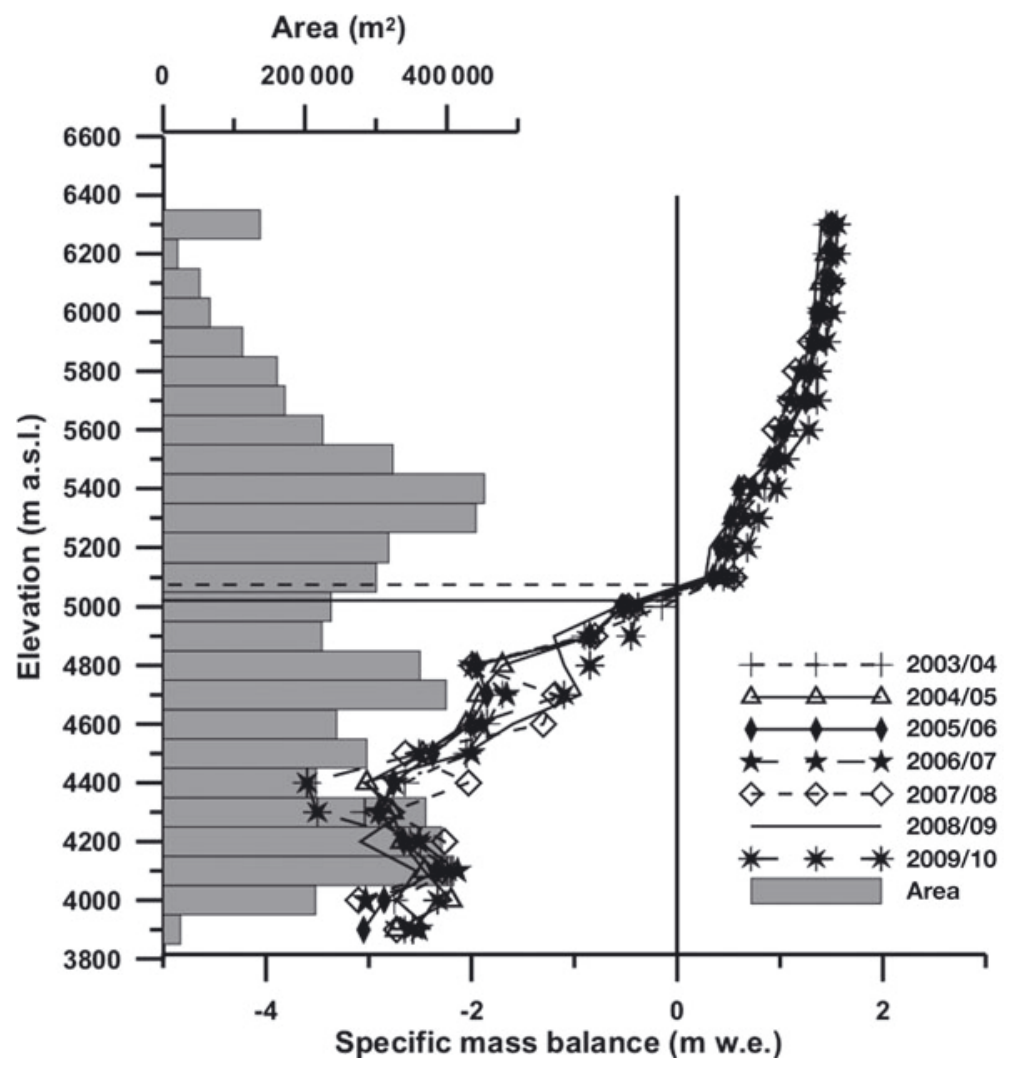

Fig. 7. Specific mass balance versus elevation (2003/04 to 2009/10) and area distribution of Chorabari Glacier derived from field measurements (stakes and pits). Between 4200 and $4500 \mathrm{~m}$ a.s.I. the glacier experiences high ablation (less debris cover) compared with lower areas (3800-4200 m a.s.I.; thick debris cover).

equilibrium line (5050-4950 m a.s.I.; Fig. 8). However, in the lower reaches between 4300 and 3895 ma.s.l. the observed elevation changes averaged $15 \mathrm{~m}$ (Fig. 8). Generally, melting at lower elevations is higher than in the upper areas; at Chorabari, this is not the case, probably due to the thick debris cover (Fig. 8).

\section{Melt rate and its correlation with debris thickness}

The altitudinal distribution of the ablation area of Chorabari Glacier, which is larger than the accumulation area, extends between 3895 and $5070 \mathrm{~m}$. Utilizing 7 years (2003-07) of ablation stake data, the distribution of melting patterns was estimated. Most surface ablation was observed between 4300 and $4500 \mathrm{~m}$, which encompasses areas covered by thin and patchy debris up to $4 \mathrm{~cm}$ thick. We

Table 4. Net mass balance, specific balance, ELA and AAR of Chorabari Glacier for the period 2003/04 to 2009/10

\begin{tabular}{lcccc}
\hline Year & $\begin{array}{c}\text { Net balance } \\
10^{6} \mathrm{~m}^{3} \text { w.e. } \mathrm{a}^{-1}\end{array}$ & $\begin{array}{c}\text { Specific balance } \\
\text { m w.e. } \mathrm{a}^{-1}\end{array}$ & $\mathrm{ELA}$ & AAR \\
& & & & \\
\hline $2003 / 04$ & -4.57 & -0.74 & 5055 & 0.45 \\
$2004 / 05$ & -4.90 & -0.79 & 5055 & 0.45 \\
$2005 / 06$ & -4.97 & -0.82 & 5070 & 0.44 \\
$2006 / 07$ & -4.50 & -0.75 & 5070 & 0.44 \\
$2007 / 08$ & -3.90 & -0.67 & 5075 & 0.44 \\
$2008 / 09$ & -4.00 & -0.67 & 5075 & 0.44 \\
$2009 / 10$ & -3.93 & -0.65 & 5070 & 0.44 \\
Average & -4.40 & -0.73 & 5067 & 0.44
\end{tabular}

suggest that a thin cover reduces albedo without significantly introducing an insulating layer at the surface. The maximum ablation rates occurring at higher altitudes $(4500 \mathrm{~m})$ were 2.3 and $3.3 \mathrm{~m} \mathrm{a}^{-1}$ at $4400 \mathrm{ma}$ a.s. . where debris layer thickness was $\sim 2 \mathrm{~cm}$ (Fig. 9a). The melting decreased with greater debris thickness and was $1.6 \mathrm{ma}^{-1}$ at $4120 \mathrm{~m}$ a.s.l., where the debris thickness was $20 \mathrm{~cm}$, and $0.75 \mathrm{~m} \mathrm{a}^{-1}$ at $4000 \mathrm{ma}$ a.s.l. with debris thickness of $53 \mathrm{~cm}$ (Fig. 9a). In order to evaluate the influence of debris cover on melting, nine stakes (between 4300 and 4400 ma.s.l.) within a $200 \mathrm{~m}^{2}$ area at locations that were debris-free or had thick $(20-50 \mathrm{~cm})$ or thin $(1-2 \mathrm{~cm})$ debris cover were monitored from 10 June to 30 July 2010 (50 days). The melting obtained for the thick debris-covered surface was $0.8 \mathrm{~cm} \mathrm{~d}^{-1}$ and for the debris-free surface and thin debris cover was 2.5 and $3.3 \mathrm{~cm} \mathrm{~d}^{-1}$, respectively. Thus, it is observed that melting reduces substantially with increased

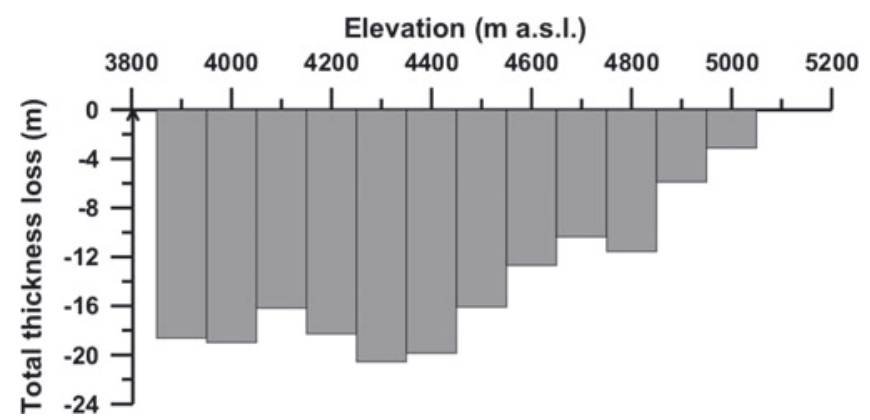

Fig. 8. Total thickness changes at different altitude bands between 2003 and 2010. 

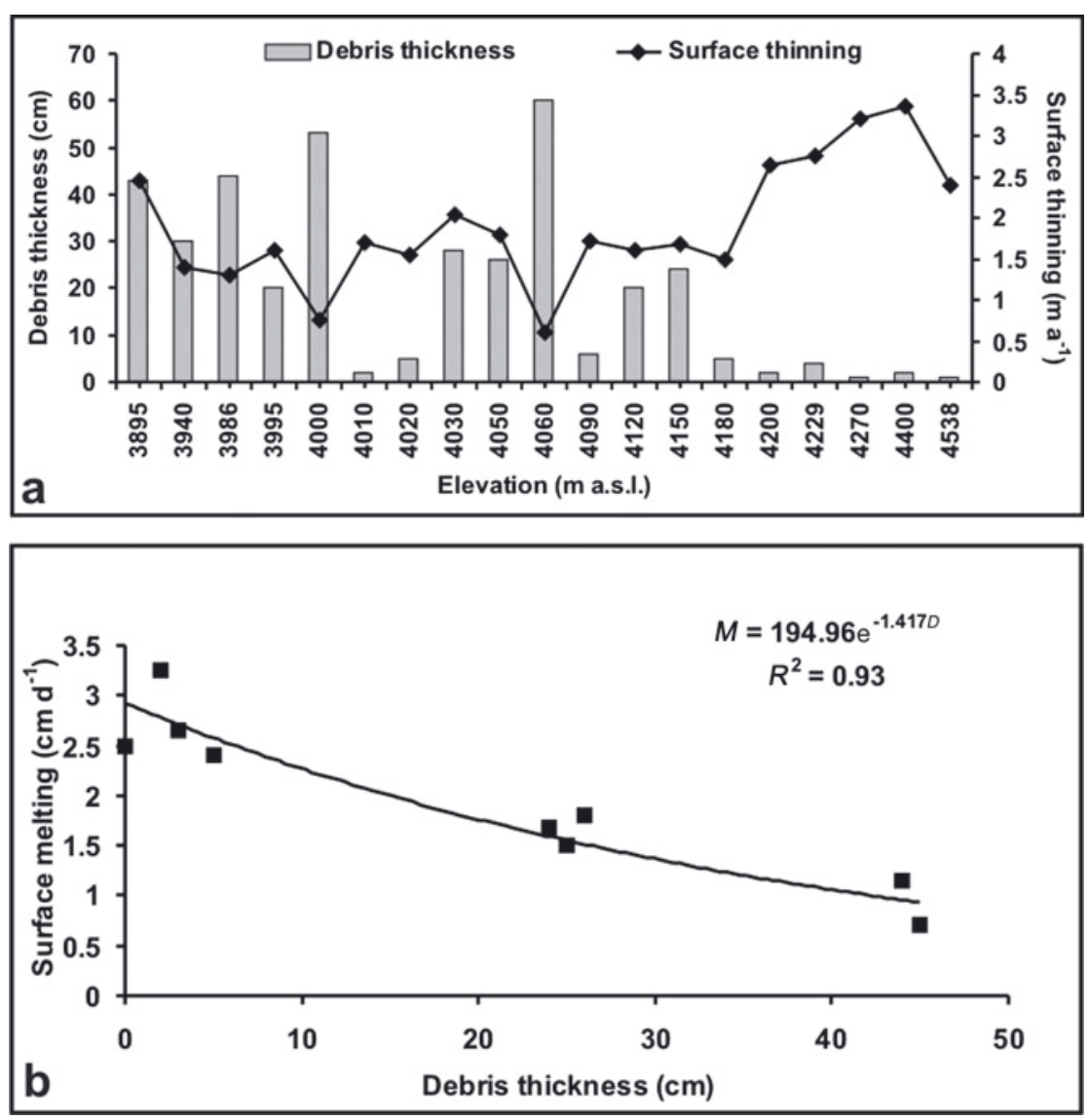

Fig. 9. (a) Relationship between debris thickness and ice melting along the centre line of Chorabari Glacier (4500 m a.s.l.) during observation periods between 2003 and 2010. (b) Relationship between debris thickness and annual melting. Observation made from 10 June to 30 July 2010 (50 days).

debris thickness. Melting in the ablation zone of Chorabari Glacier is greatest in the upper and terminus ablation areas where the glacier surface is thinly covered or is free of debris. An exponential relationship between surface melting and debris thickness shows a good correlation $\left(R^{2}=0.93\right)$ (Fig. 9b). It is postulated that the presence of supraglacial debris strongly influences glacier ablation, given otherwise similar conditions.

Our study covers an area where the number of debriscovered glaciers is high, yet very little attention has been paid to determining the influence of debris cover on glacier melting or terminus retreat. Our data indicate that a thick debris cover retards melting by shielding and insulating the glacier surface.

\section{DISCUSSION AND CONCLUSION}

Glaciers worldwide are excellent climate indicators and are therefore symbols for climate change. It has been speculated that the Himalayan glaciers are retreating faster than glaciers in other regions of the world (Cruz and others, 2007). Owing to the large geographical extent of the Himalayan mountains and regional differences in climate and topography, we cannot generalize about the state of retreat or advance of the whole system. Very few field-based measurements of glacier recession have been carried out in the Himalaya. For instance, of the nearly 10000 glaciers in the Indian Himalaya, only 11 have been studied in detail for mass balance and little more than 100 glaciers are being monitored for terminus fluctuations (Dobhal and others, 2008; Bhambri and others, 2011). There are many debris-covered glaciers that are retreating relatively slowly, such as Dunagiri $\left(3.0 \mathrm{~m} \mathrm{a}^{-1}\right)$, Shankulpa $\left(6.8 \mathrm{ma}^{-1}\right)$ and Bhagirathi Kharak $\left(1.5 \mathrm{~m} \mathrm{a}^{-1}\right)$, but many others are retreating at faster rates of up to $25 \mathrm{ma}^{-1}$ (Vohra, 1981; Swaroop and others, 2001; Nainwal and others, 2008; Raina and Srivastava, 2008). These variations in frontal recession may or may not reflect changes in mass, the critical parameter for long-term glacier health. Lack of data on volume change and ice thickness in studies in the Himalaya has hampered proper evaluation of glacier mass change in the region.

The present study of terminus, area, volume and average thickness changes by field measurement indicates that Chorabari Glacier has retreated at $6.4 \mathrm{ma}^{-1}$ (1962-2003) and $9.3 \mathrm{~m} \mathrm{a}^{-1}$ (2003-10), leading to a total area loss equivalent to $\sim 11 \%$ of its surface area during 1962-2010. However, during the later study period of 2003-10, the glacier surface lowered at $\sim 2 \mathrm{~m} \mathrm{a}^{-1}$ in the ablation zone. The mass-balance measurement over the 7 year period indicates a negative balance ranging between $-4.97 \times 10^{6} \mathrm{~m}^{3}$ w.e. in $2005 / 06$ and $-3.9 \times 10^{6} \mathrm{~m}^{3}$ w.e. in $2007 / 08$. The average net mass balance of the glacier over the 7 years (2003/04 to $2009 / 10$ ) was estimated to be $\sim-4.4 \times 10^{6} \mathrm{~m}^{3}$ w.e. $\mathrm{a}^{-1}$ with specific balance $-0.73 \mathrm{mw} . \mathrm{e} \cdot \mathrm{a}^{-1}$. The cumulative surface mass loss of $30.8 \times 10^{6} \mathrm{~m}^{3}$ w.e. over the 7 years is significant.

We suggest that the ice volume change due to melting is probably greater than earlier estimated solely from terminus position measurements. The enhanced glacier shrinkage in the higher area of Chorabari Glacier is closely related to climate change. The regional climate is mainly controlled by 
Table 5. Annual specific balance and mass loss of Himalayan glaciers in different regions of India

\begin{tabular}{|c|c|c|c|c|c|c|}
\hline \multirow[t]{2}{*}{ Glacier name } & \multirow[t]{2}{*}{ Observation period } & Glacier area & Specific balance & $\begin{array}{c}\text { Net } \\
\text { mass balance }\end{array}$ & Region & \multirow[t]{2}{*}{ Source } \\
\hline & & $\mathrm{km}^{2}$ & m w.e. $a^{-1}$ & $10^{6} \mathrm{~m}^{3}$ w.e. $\mathrm{a}^{-1}$ & & \\
\hline Neh Nar & $1975-84$ & 1.25 & -0.54 & -0.67 & Kashmir & Raina and Srivastava (2008); Raina (2009) \\
\hline Gara & 1974-82 & 5.19 & -0.37 & -1.94 & Himachal & Raina and Srivastava (2008); Raina (2009) \\
\hline Gor Gorang & $1976-84$ & 2.02 & -0.43 & -0.87 & Himachal & Raina and Srivastava (2008); Raina (2009) \\
\hline Shaune Gorang & $1981-91$ & 4.98 & -0.40 & -2.00 & Himachal & Raina and Srivastava (2008); Raina (2009) \\
\hline Dunagiri & 1984-90 & 4.39 & -0.60 & -2.66 & Uttarakhand & Raina and Srivastava (2008); Raina (2009) \\
\hline Dokriani & 1992-2000 & 7.00 & -0.32 & -2.25 & Uttarakhand & Dobhal and others (2008) \\
\hline Chorabari & $2003-10$ & 6.60 & -0.73 & -4.40 & Uttarakhand & Present study \\
\hline Changme & 1979-83 & 5.60 & -0.27 & -1.50 & Sikkim & Raina and Srivastava (2008); Raina (2009) \\
\hline
\end{tabular}

the south Asian monsoon in summer and westerlies in winter (Vohra, 1981; Owen and others, 1996; Gupta and others, 2003). In general, the terminus recession pattern of Chorabari Glacier shows that there is no uniform frontal retreat observed during the past few decades. However, the right margin of the frontal part of the glacier is almost in a stable condition (Fig. 5) and the central part is gradually retreating. Similarly, the terminus of the adjoining unnamed glacier (Fig. 2) appears to be in a stationary condition, likely due to its thick debris cover. It is observed that no change has occurred in the terminus position of this unnamed glacier since 1962. However different surface features such as meltwater ponds, ice cliffs and an undulating surface (suggesting subsurface melting) indicate shrinking of the glacier (Fig. 2). Thus, we suggest that consideration of the terminus boundary alone can lead to a poor estimate of the net mass loss for debris-covered glaciers.

As noted earlier for Chorabari Glacier, there is significant variability in melt along the length of the glacier. The ablation rate under $10 \mathrm{~cm}$ of debris is roughly one-tenth of that for clean ice; for layers $>100 \mathrm{~cm}$ the ablation becomes negligible (Mattson and others, 1993; Nakawo and others, 1999; Reznichenko and others, 2010). Reznichenko and others (2010) developed a relationship between debris cover and clean ice for surface melting and found that ice melted fastest under a $10 \mathrm{~mm}$ debris cover and less as debris thickness $(>5 \mathrm{~cm})$ increased. Similarly, Inoue and Yoshida (1980) and Nakawo and others (1999) found that for Khumbu Glacier, a heavily debris-covered glacier in the Nepal Himalaya, the change in terminus position is not a good indicator of mass change.

Across the Himalayan ranges glaciers are wasting at variable rates. The annual mean net mass balance of studied glaciers ranges between -0.67 and $-2.66 \times 10^{6} \mathrm{~m}^{3}$ w.e. $\mathrm{a}^{-1}$ except for Chorabari Glacier $\left(-4.4 \times 10^{6} \mathrm{~m}^{3}\right.$ w.e. $\mathrm{a}^{-1}$, present study) (Table 5). Nevertheless, various estimations based on in situ and satellite glacier mass balance in the entire Hindu Kush-Karakoram-Himalayan $(\mathrm{HKKH})$ region indicate heterogeneous behaviour (Cogley, 2011; Bolch and others, 2012; Gardelle and others, 2012; Kääb and others, 2012). Kääb and others (2012) reported that the specific balance across the $\mathrm{HKKH}$ glaciers as a whole during 2003-08 was $-0.21 \pm 0.05 \mathrm{~m}$ w.e. $\mathrm{a}^{-1}$ and that thinning rates were $0.66 \pm 0.09 \mathrm{~m} \mathrm{a}^{-1}$ in the Jammu Kashmir region; Gardelle and others (2012) suggest that the specific mass balance of the central Karakoram glaciers was positive $\left(0.11 \pm 0.22 \mathrm{~m}\right.$ w.e. $\left.\mathrm{a}^{-1}\right)$ between 1999 and 2008 .
The magnitude of the mass change $\left(-4.4 \times 10^{6} \mathrm{~m}^{3}\right.$ w.e. $\left.\mathrm{a}^{-1}\right)$ for Chorabari Glacier is higher than that of other glaciers in the region (Table 5). In addition, because of the gradient in debris cover, the higher-elevation areas (with less debris) have lost significantly more mass than the lower regions. If this process continue, the lower part of the glacier may remain quasi-stagnant while volume loss continues in higher glacier areas. If we assume that the debris-cover profile is relatively constant, with thin debris (and high melt) below the ELA, then a warming climate and a rise in ELA will tend to affect the higher elevations of these glaciers disproportionately. We suggest that current models and estimates based on non-debris-covered glaciers will lead to uncertainty in mass loss in a warming scenario. Although the measured rates are few in number while the number of debris-covered glaciers in the Himalaya is high, we conclude that monitoring of terminus position is not sufficient to estimate the loss and gain of ice mass. Studies need to be enhanced with observations of melt rate at different elevations with the aim of reducing uncertainty in estimates of the future ice resources of this important region.

\section{ACKNOWLEDGEMENTS}

We thank Anil K. Gupta, Director, Wadia Institute of Himalayan Geology (WIHG), Dehra Dun, India, for providing facilities to carry out this work. We also thank Robert A. Spicer and Sridhar Anandakrishanan for discussion and valuable suggestions. Rakesh Bhambri, Amit Kumar, Bhanu Thakur and Akshya Verma are acknowledged for help in the field. We also thank the Department of Science and Technology, Ministry of Science, New Delhi, India, for financial support.

\section{REFERENCES}

Ageta $\mathrm{Y}$ and Higuchi K (1984) Estimation of mass balance components of a summer-accumulation type glacier in the Nepal Himalaya. Geogr. Ann. A, 66(3), 249-255

Bhambri R, Bolch T, Chaujar RK and Kulshreshtha SC (2011) Glacier changes in the Garwal Himalaya, India, from 1968 to 2006 based on remote sensing. J. Glaciol., 57(203), 543-556 (doi: 10.3189/002214311796905604)

Bishop MP, Bonk R, Kamp U, Jr and Shroder JF, Jr (2001) Terrain analysis and data modeling for alpine glacier mapping. Polar Geogr., 25(3), 182-201 (doi: 10.1080/10889370109377712)

Bolch T, Buchroithner MF, Kunert A and Camp B (2008) Automated delineation of debris-covered glaciers based on ASTER data. 
EARSeL eProc., 403-410 http://web.unbc.ca/ bolch/publications/BolchAl07_EARSeL-iPr.pdf

Bolch Tand 10 others (2012) The state and fate of Himalayan glaciers. Science, 336(6079), 310-314 (doi: 10.1126/science.1215828)

Bookhagen B and Burbank DW (2010) Toward a complete Himalayan hydrological budget: spatiotemporal distribution of snowmelt and rainfall and their impact on river discharge. J. Geophys. Res., 115(F3), F03019 (doi: 10.1029/2009JF001426)

Bozhinskiy AN, Krass MS and Popovnin VV (1986) Role of debris cover in the thermal physics of glaciers. J. Glaciol., 32(111), 255-266

Buchroithner MF and Bolch T (2007) An automated method to delineate the ice extension of the debris-covered glaciers at Mt Everest based on ASTER imagery. Grazer Schr. Geogr. Raumforsch. 43, 71-78

Cogley JG (2011) Present and future states of Himalaya and Karakoram glaciers. Ann. Glaciol., 52(59), 69-73 (doi: 10.3189/ 172756411799096277)

Cruz RV and 9 others (2007) Asia. In Parry ML, Canziani OF, Palutikof JP, Van der Linden PJ and Hanson CE eds. Climate change 2007: impacts, adaptation and vulnerability. Contribution of Working Group II to the Fourth Assessment Report of the Intergovernmental Panel on Climate Change. Cambridge University Press, Cambridge, 469-506

Dobhal DP, Gergan JG and Thayyen RJ (2004) Recession and morphogeometrical changes of Dokriani glacier (1962-1995), Garhwal Himalayas, India. Current Sci., 86(5), 692-696

Dobhal DP, Gergan JT and Thayyen RJ (2008) Mass balance studies of the Dokriani Glacier from 1992 to 2000, Garhwal Himalaya, India. Bull. Glacier Res., 25, 9-17

Gardelle J, Berthier E and Arnaud Y (2012) Slight mass gain of Karakoram glaciers in the early 21 st century. Nature Geosci., 5(5), 322-325 (doi: 10.1038/ngeo1450)

Gupta AK, Anderson DM and Overpeck JT (2003) Abrupt changes in the Asian southwest monsoon during the Holocene and their links to the North Atlantic Ocean. Nature, 421(6921), 354-357 (doi: 10.1038/nature01340)

Higuchi K and Ohata Y (1996) Specific features of snow and ice regime under the conditions of central Asia. In Kotlyakov VM ed. Variation of snow and ice in the past and present on a global and regional scale. (International Hydrological Programme IHP-IV: Project H-41) UNESCO, Paris, 45-51

Inoue J and Yoshida M (1980) Ablation and heat exchange over the Khumbu glacier. Seppyo, J. Jpn. Soc. Snow Ice, 41, Special Issue, 26-33

Jackson KM and Fountain AG (2007) Spatial and morphological change on Eliot Glacier, Mount Hood, Oregon, USA. Ann. Glaciol., 46, 222-226 (doi: 10.3189/172756407782871152)

Kääb A, Berthier E, Nuth C, Gardelle J and Arnaud Y (2012) Contrasting patterns of early twenty-first-century glacier mass change in the Himalayas. Nature, 488(7412), 495-498 (doi: 10.1038/nature11324)

Kamp U, Byrne M and Bolch T (2011) Glacier fluctuations between 1975 and 2008 in the Greater Himalaya Range of Zanskar, southern Ladakh. J. Mt. Sci., 8(3), 374-389 (doi: 10.1007/ s11629-011-2007-9)

Kulkarni AV, Rathore BP, Mahajan S and Mathur P (2005) Alarming retreat of Parbati Glacier, Beas basin, Himachal Pradesh. Current Sci., 88(11), 1844-1850

Kulkarni AV and 6 others (2007) Glacial retreat in Himalaya using Indian remote-sensing satellite data. Current Sci., 92(1), 69-74

Lougeay R (1974) Detection of buried glacial and ground ice with thermal infrared remote sensing. In Santeford HS and Smith JL eds. Advanced concepts and techniques in the study of snow and ice resources. National Academy of Sciences, Washington, DC, 487-493

Lundstrom SC, McCafferty AE and Coe JA (1993) Photogrammetric analysis of 1984-89 surface altitude change of the partially debris-covered Eliot Glacier, Mount Hood, Oregon, USA. Ann. Glaciol., 17, 167-170
Mattson LE, Gardner JS and Young GJ (1993) Ablation on debriscovered glaciers: an example from the Rakhiot Glacier, Punjab, Himalaya. IAHS Publ. 218 (Symposium at Kathmandu 1992 Snow and Glacier Hydrology), 289-296

Mehta M, Dobhal DP and Bisht MPS (2011) Change of Tipra Glacier in the Garhwal Himalaya, India, between 1962 and 2008. Progr. Phys. Geogr., 35(6), 721-738 (doi: 10.1177/ 0309133311411760)

Mehta M, Majeed Z, Dobhal DP and Srivastava P (2012) Geomorphological evidences of post-LGM glacial advancements in the Himalaya: a study from Chorabari Glacier, Garhwal Himalaya, India. J. Earth Syst. Sci., 121(1), 149-163 (doi: 10.1007/s12040-012-0155-0)

Mehta M, Dobhal DP, Pratap B, Verma A, Kumar A and Srivastava D (2013) Glacier changes in Upper Tons River basin, Garhwal Himalaya, Uttarakhand, India. Z. Geomorph., 57(2), 225-244 (doi: 10.1127/0372-8854/2012/0095)

Nainwal HC, Negi BDS, Chaudhary M, Sajwan KS and Gaurav A (2008) Temporal changes in rate of recession: evidence from Satopanth and Bhagirath Kharak Glaciers, Uttarakhand, using Total Station Survey. Current Sci., 94(5), 653-660

Nakawo M, Yabuki H and Sakai A (1999) Characteristics of Khumbu Glacier, Nepal Himalaya: recent changes in the debris-covered area. Ann. Glaciol., 28, 118-122 (doi: 10.3189/172756499781821788)

Østrem G (1965) Problems of dating ice-cored moraines. Geogr. Ann. A, 47(1), 1-38

Østrem G and Brugman M (1991) Glacier mass-balance measurements: a manual for field and office work. (NHRI Science Report 4) National Hydrology Research Institute, Environment Canada, Saskatoon, Sask.

Owen LA, Derbyshire E, Richardson S, Benn DI, Evans DJA and Mitchell WA (1996) The Quaternary glacial history of the Lahul Himalaya, northern India. J. Quat. Sci., 11(1), 25-42 (doi: 10.1002/(SICI)1099-1417(199601/02)11:1<25::AIDJQS209>3.0.CO;2-K)

Paul F, Huggel C and Kääb A (2004) Combining satellite multispectral image data and a digital elevation model for mapping debris-covered glaciers. Remote Sens. Environ., 89(4), 510-518 (doi: 10.1016/j.rse.2003.11.007)

Prasada Raju PVSP and Ghosh S (2003) Role of remote sensing and digital cartography in sustainable development. Indian Cartogr., 23, 88-95

Raina VK (2009) Himalayan glaciers: a state-of-art review of glacial studies, glacial retreat and climate change. MoEF Discussion Paper. Ministry of Environment and Forests, Government of India/GB Pant Institute of Himalayan Environment and Development, New Delhi/Kosi-Katarmal, Almora http:// indiaenvironmentportal.org.in/files/MoEDiscussionPaper.pdf

Raina VK and Srivastava D (2008) Glacier atlas of India. Geological Society of India, Bangalore

Reznichenko N, Davies T, Shulmeister J and McSaveney MJ (2010) Effects of debris on ice-surface melting rates: an experimental study. J. Glaciol., 56(197), 384-394 (doi: 10.3189/ 002214310792447725)

Scherler D, Bookhagen B and Strecker MR (2011) Spatially variable response of Himalayan glaciers to climate change affected by debris cover. Nature Geosci., 4(3), 156-159 (doi: 10.1038/ ngeo1068)

Shukla A, Gupta RP and Arora MK (2009) Estimation of debris cover and its temporal variation using optical satellite sensor data: a case study in Chenab basin, Himalaya. J. Glaciol., 55(191), 444-452 (doi: 10.3189/002214309788816632)

Stokes CR, Popovin V, Aleynikov A, Gurney SD and Shahgedanova M (2007) Recent glacier retreat in the Caucasus Mountains, Russia, and associated increase in supraglacial debris cover and supra-/proglacial lake development. Ann. Glaciol., 46, 195-203 (doi: 10.3189/172756407782871468)

Survey of India (1962) Topographic map of Chorabari Glacier, 1:50000 scale; $40 \mathrm{~m}$ contour interval (planimetric accuracy 
$\pm 12.5 \mathrm{~m}$ and elevation accuracy $\pm 6.5 \mathrm{~m})$. Survey of India, Dehra Dun

Swaroop S, Oberoi K, Srivastava D and Gautam CK (2001) Recent fluctuations in snout front of Dunagiri and Chaurabari glaciers, Dhauliganga and MandakiniAlaknanda basins, Chamoli district, Uttar Pradesh. In Proceedings of the Symposium on Snow, Ice and Glaciers - a Himalayan Perspective, 9-11 March 1999, Lucknow, India. (Special Publication 53) Geological Survey of India, Lucknow, 77-81

Taschner S and Ranzi R (2002) Comparing the opportunities of Landsat-TM and ASTER data for monitoring a debris-covered glacier in the Italian Alps within the GLIMS project. In 22nd International Geoscience and Remote Sensing Symposium (IGARSS 2002), 24-28 June 2002, Toronto, Canada. Proceedings, Vol. 2. Institute of Electrical and Electronics Engineers, Piscataway, NJ, 1044-1046

Vohra CP (1981) Himalayan glaciers. In Lall JS and Moddie AD eds. The Himalaya: the aspects of change. Oxford University Press, Delhi, 138-151

Wagnon P and 10 others (2007) Four years of mass balance on Chhota Shigri Glacier, Himachal Pradesh, India, a new benchmark glacier in the western Himalaya. J. Glaciol., 53(183), 603-611 (doi: 10.3189/002214307784409306)

MS received 28 September 2012 and accepted in revised form 10 June 2013 